IZADP No. 2037

Reconstructing School Segregation:

On the Efficacy and Equity of Single-Sex Schooling

Sherrilyn M. Billger

March 2006 


\title{
Reconstructing School Segregation: On the Efficacy and Equity of Single-Sex Schooling
}

\author{
Sherrilyn M. Billger \\ Illinois State University \\ and IZA Bonn
}

\section{Discussion Paper No. 2037 \\ March 2006}

\author{
IZA \\ P.O. Box 7240 \\ 53072 Bonn \\ Germany \\ Phone: +49-228-3894-0 \\ Fax: +49-228-3894-180 \\ Email: iza@iza.org
}

\begin{abstract}
Any opinions expressed here are those of the author(s) and not those of the institute. Research disseminated by IZA may include views on policy, but the institute itself takes no institutional policy positions.

The Institute for the Study of Labor (IZA) in Bonn is a local and virtual international research center and a place of communication between science, politics and business. IZA is an independent nonprofit company supported by Deutsche Post World Net. The center is associated with the University of Bonn and offers a stimulating research environment through its research networks, research support, and visitors and doctoral programs. IZA engages in (i) original and internationally competitive research in all fields of labor economics, (ii) development of policy concepts, and (iii) dissemination of research results and concepts to the interested public.
\end{abstract}

IZA Discussion Papers often represent preliminary work and are circulated to encourage discussion. Citation of such a paper should account for its provisional character. A revised version may be available directly from the author. 


\title{
ABSTRACT \\ Reconstructing School Segregation: On the Efficacy and Equity of Single-Sex Schooling
}

\begin{abstract}
A change to Title IX has spurred new single-sex public schooling in the US. Until recently, nearly all gender-segregated schools were private, and I therefore address potential selection bias in the effects on educational and labor market outcomes using within private sector comparisons, an index comparing expectations to outcomes, quantile regressions, and other techniques. Descriptive statistics suggest significant benefits, but more consideration of selection bias reveals less consistency. Girls' school alumnae are more likely than their coed peers to receive scholarships, but they are not more likely to pursue college degrees, and both genders are less likely to meet their own educational expectations. Moreover, single-sex schooling is not universally superior in supporting gender equity, as coeducational public schools yield the least segregated college major choices. On the other hand, I find $15-20 \%$ higher starting salaries among single-sex school graduates, but only persistently for men of median ability. Much of the benefit from single-sex schooling accrues to students already likely to succeed, but favorable selection is an insufficient explanation for all gains. Most notably, there are clear returns for both African-Americans and low income students.
\end{abstract}

JEL Classification: $\quad 121, \mathrm{~J} 24, \mathrm{~J} 3,128$

Keywords: $\quad$ single-sex education, labor outcomes, secondary schooling, gender

Corresponding author:

Sherrilyn M. Billger

Department of Economics

Illinois State University

Campus Box 4200

Normal, IL 61790-4200

USA

Email: smbillg@ilstu.edu

\footnotetext{
* I am grateful to Dan Rich, seminar participants at IZA, and participants at the APPAM and SOLE/EALE conferences for helpful comments and discussion.
} 


\section{Introduction}

In response to a relatively minor clause in the "No Child Left Behind" Act, the Department of Education has promoted amendments to Title IX that allow for single-sex public schools and classes (Federal Register, 2004). In fact, in response to this announcement, there are 44 singlesex public schools and 167 schools have instituted separate-gender classes (as of Spring 2006). ${ }^{1}$ Such a quick response is surprising, given that official changes have not yet been announced by Department of Education. The stated goal of this change to Title IX is that greater choice will improve educational outcomes for both boys and girls. Unfortunately, there is no direct evidence that such a change would indeed improve outcomes for all involved students, mostly because nearly all existing single-sex programs are within private schools, where resources and student backgrounds are quite different from those at many public schools.

Relevant literature within Economics is quite limited, where most work focuses on peer or role model effects rather than single-sex schooling directly. For instance, Hoxby (2000) finds that classes with more female students performed better in certain subjects. Though indirectly related to the topic at hand, were these results taken to the extreme, the impact on boys and girls would not be equal. Indeed, one of the important issues within this debate is whether such school segregation is beneficial for both genders, in terms of both academics and acculturation.

According to Solnick (1995), students at women's colleges were more likely to shift into traditionally male fields, leading to better labor market success. Billger (2002) studies a college that switched from all-female to coeducation and finds that women were more likely to pursue majors in science and math before the institution admitted men. The source of these differences

\footnotetext{
${ }^{1}$ National Association for Single Sex Public Education, http://www.singlesexschools.org/, accessed March 2006.
} 
likely arises from a combination of personal and institutional characteristics. For instance, single-sex schools and colleges may highlight the positive effects of same-gender role models in front of the classroom. Using data from the NLS72, Rothstein (1995) examines the effect of female faculty on female college students. She documents a higher probability of advanced degree attainment with more women on a department's faculty. On the other hand, Canes and Rosen (1995) find that increasing the number of female faculty does not lead to more female majors. Investigating $8^{\text {th }}$ grade student and teacher across genders, Ehrenberg et al. (1995) reveal no significant role model effect on student learning; gain scores are no higher when a student learns from a teacher of the same gender. Taken together these results provide, at best, lukewarm support for separate-gender classes and schools.

In this paper I investigate whether single-sex schooling leads to improved labor market outcomes for alumni. With survey data from the National Center for Education Statistics, I address degree attainment and salaries, controlling for personal, family, school, and community characteristics. I use a variety of techniques to address selection bias. Indeed, single-sex schools with particular admission requirements are, a priori, likely to generate improved student outcomes. I therefore begin with selection-corrected benchmarks from common two-step techniques. I also compare attainment to earlier expectations. Does this schooling impart gains or do students simply meet their prior goals? Comparisons of college majors reveal whether school affiliation reinforces traditional gender roles. In addition, I explore correlations between innate ability, school characteristics, and outcomes using quantile regressions. Finally, comparisons both within and across gender highlight potential costs and benefits to public single-sex schooling. 


\section{Single-Sex Schools}

The main data set used in this analysis is the National Educational Longitudinal Study (NELS), a panel survey from the National Center for Education Statistics. A representative sample of eighth graders was interviewed in 1988, then subsequently in 1990, 1992, 1994, and 2000. These data include detailed information about students, families, schools, communities, and teachers. Data from the Private School Survey were then merged by zip code to identify whether a respondent lived near a single-sex school. Data from the Integrated Postsecondary Education Data System provide college and university characteristics. In addition, data from the Occupational Employment Statistics program at the Bureau of Labor Statistics have been included to identify median wages by occupation.

In Table 1 I report summary statistics separately by gender for private single sex education (SSE), private coeducation, and public coeducation. These categories are determined from the $10^{\text {th }}$ grade school survey which asked each school directly whether it was coeducational, all-girls, or all-boys. Eighth grade test scores reveal that both girls and boys who attend single-sex schools have consistently higher average academic scores than their counterparts at public coeducational institutions. Also, students at these schools are unsurprisingly more likely to live near a single-sex school. On the other hand, gender differences emerge in family income, revealing that among private schools, more girls of lower socioeconomic status pursue SSE. A majority of students expect to attend college, and significantly more of the single-sex (male) alumni have this plan, even among private schools. Interestingly, none of the girls' school graduates in this survey chose a women's college. Graduates from private schools have higher degree attainment by 2000, which is eight years after $12^{\text {th }}$ grade. Though SSE alumni pursue more education, this difference is not statistically 
significant across private schools. Relative to coed private schools, the gains from single-sex schooling may be greater for women than men, with $11 \%$ higher starting salaries but virtually identical salaries for men.

I assume that parents (or guardians) are primarily responsible for a student's decision to pursue SSE. Potentially relevant factors include location, family income, student ability and preferences, and public school quality. To investigate the likelihood that a student will attend a single sex school, I estimate a probit for this decision separately by gender:

$$
\operatorname{Prob}\left(\operatorname{singsexsch}_{i}=1 \mid X_{i}\right)=\Phi\left(X_{i} \beta\right)
$$

where $X$ is a matrix of personal characteristics including: race, family socioeconomic status (SES), $8^{\text {th }}$ grade test scores, college expectations, religious participation, urban and regional residence, proximity to single-sex schools, proportion minorities and free lunch in $8^{\text {th }}$ grade school, whether afraid to ask questions, gifted program enrolment, flunked a grade, and parental involvement.

At the time of the NELS surveys, nearly all SSE was privately controlled, suggesting that socioeconomic status is particularly relevant to this decision. In addition, these schools are more common in urban areas in the northeast and south, and a student living nearby is more likely to attend. Much SSE is Catholic or otherwise religiously-affiliated, so religious participation may be positively correlated with matriculation. The percentage of students who are minorities, and those eligible for free lunches, reflect the public school climate in $8^{\text {th }}$ grade, and may affect a parent's decision to enroll their child elsewhere. Participation in gifted programs and whether a student has been held back a grade reflect ability and student behavior. Parental involvement is revealed by whether the student has spoken with their parent/guardian about school in recent months. Finally, many sociological studies assert that students pursue SSE because they feel 
intimidated in coeducational environments. I investigate this hypothesis with an indicator for whether the student expressed fear about answering questions in math and/or science classes in $8^{\text {th }}$ grade.

Table 2 reports probit results by gender for the full sample and the private school subsamples. Marginal effect estimates and coefficient standard errors are reported. Marginal effects for continuous covariate $j$ are calculated as follows:

$$
\frac{\partial p_{i}}{\partial x_{i j}}=\phi\left(X_{i} \beta\right) \beta_{j}
$$

where $\phi(\cdot)$ is the standard normal density function. For each indicator explanatory variable $k$, the marginal effect is:

$$
\frac{\partial p_{i}}{\partial x_{i k}}=\Phi\left(\beta_{1}+\beta_{2} x_{2 i}+\cdots+\beta_{k-1, i} x_{k-1, i}+\beta_{k}\right)-\Phi\left(\beta_{1}+\beta_{2} x_{2 i}+\cdots+\beta_{k-1, i} x_{k-1, i}\right)
$$

In some cases, it appears that higher ability induces attendance, though not universally. Among only private school students, girls at SSE are more likely to be from lower income classes, while the opposite is true for boys. College expectations are insignificant to the decision for girls, but very important for boys. Proximity to SSE is unsurprisingly significant, but dwarfed by the marginal effect of urban residence. A potentially surprising result emerges, in that religious participation is negatively correlated with SSE matriculation. It is also interesting that, among private school students, girls who were afraid to participate in class in eighth grade are $32 \%$ more likely to attend a girls' school in tenth grade.

\section{Educational and Labor Market Outcomes}

Degree Attainment 
It has become rather common for many high school graduates to pursue college education, suggesting little variation in this outcome. It is nevertheless valuable to explore whether certain school characteristics and school types induce greater receipt of 4-year degrees. I begin with probit estimates for the likelihood of receiving bachelor's degrees within 8 years of graduating high school:

$$
\left.{\text { Prob }\left(\text { earn4yrdegree }_{i}=1 \mid X_{i}, S_{i}\right. \text {, have HS diploma }}_{i}\right)=\Phi\left(X_{i} \delta+S_{i} \gamma\right)
$$

where $X$ is a matrix including race, socioeconomic status (SES), HS rank, $8^{\text {th }}$ grade test scores, parents' education, region, gifted program enrolment, SAT score, and SAT missing indicator. $S$ is a matrix with an indicator for private school and another for private SSE, and the probit is estimated accounting for clustering and stratification across observations in the same strata and school. As in Table 2, marginal effects and parameter standard errors are reported. Results in Columns 1 and 4 of Table 3 display the expected signs, as income and SAT scores are positively correlated with degree attainment. Higher high school rank corresponds to worse performance and is significantly negatively correlated with earning a bachelor's degree. Conditional on personal characteristics, private school graduates are over $13 \%$ more likely to earn a BA/BS, but there is no supplemental benefit from SSE. This result supports that hypothesis that apparent gains from SSE are upward biased by selection.

To investigate this selection bias in a different way, I generate an index to compare attainment by eight years after graduation to prior expectations. Specifically, in eighth grade respondents were asked, “How far in school do you think you will get?” I begin by ordering degree levels, including high school drop-outs through advanced degrees, and each level is assigned a one point step. The index is then the difference between receipt and expectation:

$$
\text { AttExp }_{i}=\text { Degree Attained by } 2000_{i}-\text { Degree Expected in } 1988 \text { in } 8^{\text {th }} \text { Grade }_{i}
$$


AttExp equals zero when the respondent attained exactly the degree expected. For instance, a student who expects to obtain some technical training after high school but actually drops out before $12^{\text {th }}$ grade would have a value of -2 . Another student who expects to finish college and in fact pursues graduate work would have a value of 1 .

The index is not significantly different among women when comparing SSE to coeducation. For men, however, the distribution is significantly different, even among private schools, according to Pearson $\chi^{2}$ tests. I present the distribution of the index in Figure 1. Among SSE alumnae, expectations are less frequently met, while public coed schools have the highest mode for meeting goals. If SSE truly imparted benefits on students, we might expect the opposite result. It is nonetheless possible that expectations are unmet if the effects of fertility, institutions, etc. are disproportionately negative for SSE alumnae with otherwise lofty goals. It is also possible that eight years is not a sufficiently long window for all interested women to obtain advanced degrees. Single sex education is similarly less beneficial among alumni, where Catholic and public school graduates are more likely to meet or exceed their expectations.

Perhaps gains would not accrue uniformly, and Figure 1 displays additional distributions among African-Americans and low SES respondents. However, within both genders, and within each category, the distributions for SSE alumni appear to have greater mass in the left tail and less in the right. It is also important to note that cell sizes are quite small in some cases, so inference is not entirely appropriate. It remains the case, however, that none of the evidence reported in Figure 1 runs counter to the selection bias hypothesis.

I next analyze the index parametrically, by estimating an ordered logit model which assumes the latent variable:

$$
\operatorname{AttExp}_{i}{ }^{*}=x_{i} \eta+u_{i} \quad \operatorname{AttExp}_{i}=-4,-3, \ldots, 3
$$


This latent variable represents increasing attendance relative to expectations, and the error term $u_{i}$ is assumed to be logistic distributed. The estimated parameter signs reveal whether the latent variable increases as the respective regressor increases. I estimate (6) with covariates identical to those in (4). Coefficients and robust standard errors appear in columns 2 and 4 of Table 3. Private school attendance benefits female students, but SSE has no significant effect on either gender.

NELS also reports whether respondents received a college grant or scholarship, and using these data I estimate the likelihood of obtaining this aid:

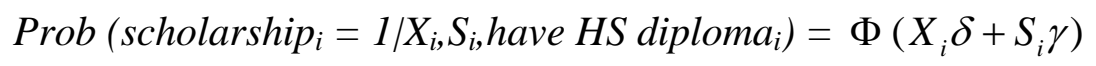

In this case all independent variables are as defined in (5), though parameters are expected to vary from that. Results appearing in columns 3 and 6 of Table 3 reveal important differences by gender. Controlling for family SES, girls’ school graduates are $11 \%$ more likely to receive aid, while alumni are $11 \%$ less likely. It therefore appears that SSE alumnae face lower average human capital investment costs, ceteris paribus, but are not more likely to complete bachelor's degrees or to meet their own educational expectations.

Proponents of separate gender education claim that gender stereotypes are not reinforced, and students become more confident and more willing to pursue the fields that most interest them. I investigate this claim using data on college major choice at the first post-secondary institution attended. Presumably, before much time has passed, a student's secondary school experience influences their choices in college. Table 4 lists the distribution of students across major field by gender and school type. Majors are sorted according to the distribution of females from public secondary schools, and popular majors such as education, health, and business appear near the bottom. Women from coed schools are substantially more likely to pursue 
degrees in education, with more single-sex graduates in science, literature, and communications. Male single-sex alumni are more likely to pursue business, philosophy/religion, and secretarial skills. I also calculate the Duncan index (Duncan and Duncan, 1955) so that the overall level of segregation may be ascertained.

$$
D_{j}=\frac{\sum\left|\frac{A_{i}}{X}-\frac{B_{i}}{Y}\right|}{2} \quad j=1,2,3
$$

Where $A$ and $B$ are women and men, respectively, and $X$ and $Y$ represent the total number of women and men in each sample. The school types $j$ include SSE, private coed, and public coed. An index value equal to zero denotes no segregation and 100 denotes full segregation.

The greatest degree of segregation occurs among alumni of coed private schools, and there appears to be less segregation among public school graduates. These results relate well to Wootton’s (1997) findings on occupational differences by gender. For instance, women’s participation in managerial positions has greatly increased in recent years, while men are somewhat more likely to be in administrative support jobs. While there is less segregation in SSE compared to private coed schools, this evidence suggests that overall, gender stereotypes may be less prevalent in mixed gender public schools.

\section{Salaries}

Income reported in 1999 constitutes a starting-level salary for most respondents. I predict starting salaries as a function of personal and school characteristics:

$$
\text { Isalary }_{i}=f\left(X_{i}, S_{i}\right)
$$

where $X_{i}$ includes race, degree attainment, hours worked, marital status, children, urban residence, SAT score, and SAT missing indicator. $S_{i}$ is a matrix with private and private single- 
sex school indicators. I initially use a standard linear functional form and estimate conditional means with OLS regressions:

$$
E\left(\text { Isalary }_{i} \mid X_{i}\right)=X_{i} \beta
$$

Results are reported in Table 5. Graduates of these schools earn higher average salaries than their peers, men $17 \%$ and women $16 \%$. A robustness check run with only graduates of private secondary schools reveals a greater return for men at $20 \%$ and a slightly lower return for women at $12 \%$.

In order to address selection bias in a different way, I use quantile regressions as developed in Koenker and Bassett (1978). Regression coefficients are estimated at a number of quantiles in the conditional distribution of salary, thereby extending beyond mean effects available through OLS.

$$
\text { Quant }_{\theta}\left(\text { Isalary }_{i} \mid X_{i}\right)=X_{i} \beta_{\theta}
$$

where $\theta \in(0,1)$. Furthermore, the conditional distribution of salary is highly related to ability or on the job performance that is unobservable to researchers. Thus, quantile regression results provide evidence about which students are mostly likely to experience wage gains, given their location in the conditional salary distribution. If the "best and brightest" are more likely to attend single-sex schools and to perform very well on the job, we would expect positive and significant returns at upper quantiles. This would provide some evidence of positive selection bias in returns. Furthermore, coefficient estimates that increase monotonically support the hypothesis of selection bias, while decreasing monotonicity refutes it. Coefficients that are least negative or most positive at lower quantiles reveal the greatest gains for the "least able."

As seen in Table 5, benefits for women are not uniform, and test significant only near the median. This suggests that 1) significant benefits may not accrue to the "best" and "worst" 
workers and 2) the returns to single-sex schooling are not uniform across innate ability. On the other hand, gains for men appear stronger, with substantially higher wages for even the lowest ability workers. Significant benefits of $23 \%$ higher salaries remain at the median among private school alumni, though not necessarily for workers in either tail of the conditional distribution.

Starting salaries may not reflect a worker’s long-term earning prospects. I therefore incorporate data on median salary by occupation (from the BLS Occupational Employment Statistics), and merge these by the occupation each respondent reported in 2000. OLS and quantile regression results are listed in Table 6. According to this specification, single-sex schooling yields monotone increasing coefficients for women, supporting the selection bias hypothesis. On the other hand, only the left half of the men's conditional distribution is affected, and SSE yields no benefit in most cases. Unfortunately, these results are likely impacted by the decreased variation in the dependent variable, given that only 39 different occupations are reported in the NELS.

I also analyze starting salaries using switching regressions to address selection bias. Suppose there are two regimes, one for SSE, and the other for coeducation:

$$
\text { Isalary }_{i j}=X_{i} \beta_{j} \quad j: \text { SSE or } C
$$

A latent indicator function determines SSE attendance and whether lsalary $y_{S E}$ or Isalary $_{C}$ is observed. To estimate this model, I incorporated all significant regressors from specification (1) in the first stage. Inverse mills ratios were then included in the second stage wage regressions. ${ }^{2}$

\footnotetext{
2 To address possible concerns about weak instruments, I only use significant regressors in the first stage. In addition, regressions on predicted wage residuals including the instruments yield very low R-squared values, and it appears that instruments are insignificant in reduced form wage regressions.
} 
Resulting salary predictions are reported in Table 7 by gender and school type for a variety of characteristics. Controlling for selection into these schools, African-Americans experience large salary gains relative to their coed peers. In addition, it appears that SSE alumnae may be able to "catch up" to their male peers from coeducational schools, with large investments in education.

\section{Is it Just the Catholic Effect?}

Many studies have examined the effect of Catholic schooling on students, reaching an apparent consensus that these students are significantly more likely to finish high school. ${ }^{3}$ According to Grogger and Neal (2000) urban minorities fare particularly well in terms of educational outcomes. On the other hand, Sander and Krautmann (1995) find that graduates are not more likely to pursue college education, though Altonji et al. (2005b) suggest college attendance may be enhanced. It is certainly true that many single-sex schools are Catholic, and additional robustness tests are warranted.

Within this NELS sample, $80 \%$ of the boys' school students are at Catholic schools, but that is true for only $51 \%$ of the females (not an overwhelming majority). I have estimated the probability of obtaining bachelor's degrees with additional regressors for religious and secular schools, as well as interaction terms. I find no significant effects. Another robustness test involved augmented starting salary regressions. Estimated OLS and quantile regression

\footnotetext{
${ }^{3}$ In addition to those mentioned, Evans and Schwab (1995) and Neal (1997) confirm the positive correlation between Catholic school attendance and H.S. diploma attainment. Sander (1995) reports that eight years of Catholic primary schooling yield higher test scores, while Jepsen (2002) finds that Catholic primary schooling has no effect on later scores. Altonji et al. (2005a) discuss important caveats for the predicted effects of Catholic school attendance.
} 
coefficients appear in Figure 2. The effect of girls' school attendance increases through conditional quantiles. We also see a positive benefit to religious single-sex schooling for girls at the left tail of the conditional salary distribution, and much lower gains for the right tail. For those with lower unobserved performance, a Catholic girls' school may generate significant gains. The effect of boys' schooling appears greater up to the median. For men, Catholic schooling is particularly beneficial for those earning (conditionally) lower salaries, but SSE Catholic schooling yields lower income. As a final robustness check, I have also run this analysis on Catholic school attendance, rather than SSE. Descriptively, Catholic school students have lower test scores and similar incomes, much like the private coed sample. Compared to non-Catholic private schools, I also find no direct effect on degree attainment, scholarships, or starting salaries.

\section{Efficacy and Equity in Public Single-Sex Education}

To truly evaluate public single-sex education, it is necessary to consider not only the resulting outcomes for alumni, but also the equity in both implementation and long-term effects. Results presented in this analysis suggest limited benefits for graduates. A variety of estimates imply higher salaries, particularly for those of median ability. And compared to other private schools, single-sex institutions lead to less gender segregation in college major, but coed schools fare even better in this respect. A possible explanation is the reinforcement of gender stereotypes at single sex schools (as some detractors claim). It is also somewhat troubling that SSE alumni are unlikely to meet their educational expectations. There appears to be no significant difference in receipt of BA/BS degrees, though SSE alumnae are more likely to obtain scholarships. Taken together, these results do not provide a ringing endorsement of single-sex education. 
Some positive prospects do nonetheless arise. First, predicted salaries for alumnae of girls’ schools are often similar to alumni from coeducational schools, suggesting enhanced gender equity through higher salaries for some women. In addition, African-American students experience unique gains, and single-sex education may therefore provide an important opportunity to continued improvements in educational quality and outcomes for AfricanAmericans. 


\section{References}

Altonji, Joseph G., Todd E. Elder, and Christopher R. Taber. (2005a) “An Evaluation of Instrumental Variable Strategies for Estimating the Effects of Catholic Schooling,” The Journal of Human Resources, 40(4), 791-821.

Altonji, Joseph G., Todd E. Elder, and Christopher R. Taber. (2005b) "Selection on Observed and Unobserved Variables: Assessing the Effectiveness of Catholic Schools,” Journal of Political Economy, 113(1), 151-84.

American Association of University Women Educational Foundation. (1998) Separated by Sex: A Critical Look at Single-Sex Education for Girls.

Billger, Sherrilyn M. (2002) “Admitting Men into a Women’s College: A Natural Experiment,” Applied Economics Letters, 9, 479-83.

Canes, Brandice J., and Harvey S. Rosen. (1995) "Following in Her Footsteps? Faculty Gender Composition and Women's Choices of College Majors,” Industrial and Labor Relations Review, 48(3), 486-504.

Duncan, Otis D., and Beverly Duncan. (1955) “A Methodological Analysis of Segregation Indexes,” American Sociological Review, 20(2), 210-17.

Ehrenberg, Ronald G., Daniel D. Goldhaber, and Dominic J. Brewer. (1995) “Do Teachers’ Race, Gender, and Ethnicity Matter? Evidence from the National Educational Longitudinal Study of 1988,” Industrial and Labor Relations Review, 48(3) 547-61.

Evans, William N., and Robert M. Schwab. (1995) "Finishing High School and Starting College: Do Catholic Schools Make a Difference?” Quarterly Journal of Economics, 110(4), 941-74.

Grogger, Jeffrey, and Derek Neal. (2000) "Further Evidence on the Effects of Catholic Secondary Schooling,” Brookings-Wharton Papers on Urban Affairs, 151-201.

Hoxby, Caroline M. (2000) "The Effects of Class Size and Composition on Student Achievement: New Evidence from Natural Population Variation,” Quarterly Journal of Economics, 115(4), November, 1239-85.

Jepsen, Christopher. (2002) “The Effectiveness of Catholic Primary Schooling,” The Journal of Human Resources, 38(4), 928-41.

Koenker, Roger, and Gilbert Bassett, Jr. (1978) “Regression Quantiles,” Econometrica, 46(1), 33-50.

Neal, Derek. (1997) "The Effects of Catholic Secondary Schooling on Educational Achievement,” Journal of Labor Economics, 15(1), 98-123. 
Rothstein, Donna S. (1995) “Do Female Faculty Influence Female Students’ Educational and Labor Market Attainments?” Industrial and Labor Relations Review, 48(3), 515-29.

Salomone, Rosemary C. (2003) Same, Different, Equal: Rethinking Single-Sex Schooling, New Haven: Yale University Press.

Sander, William. (1995) “Catholic Grade Schools and Academic Achievement,” The Journal of Human Resources, 31(3), 540-8.

Sander, William, and Anthony C. Krautmann. (1995) “Catholic Schools, Dropout Rates and Educational Attainment,” Economic Inquiry, 33, 217-33.

Solnick, Sara J. (1995) “Changes in Women’s Majors From Entrance to Graduation at Women’s and Coeducational Colleges,” Industrial and Labor Relations Review, 48(3), 505-14.

U.S. Department of Education. (2004) "Nondiscrimination on the Basis of Sex in Education Programs or Activities Receiving Financial Assistance; Proposed Rules,” Federal Register, 34 CFR Part 106, 9 March.

Wootton, Barbara H. (1997) “Gender Differences in Occupational Employment,” Monthly Labor Review, April, 15-24. 
Figure 1. Educational Attainment Relative to Expectations

Zero: Attainment $=$ Expectation

\section{Females}

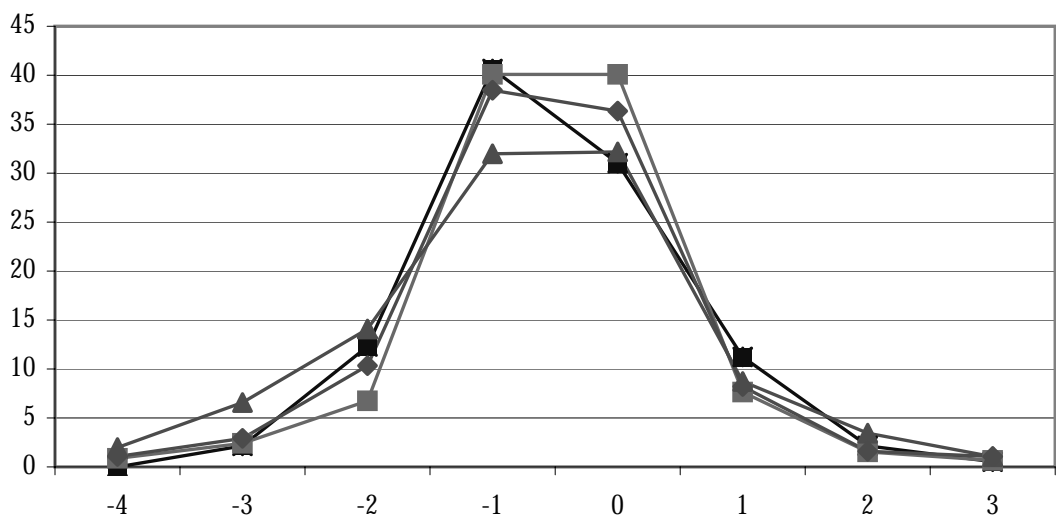

Single-Sex School $\multimap-$ Private Coed School $\multimap-$ Public School $\multimap$ Catholic School

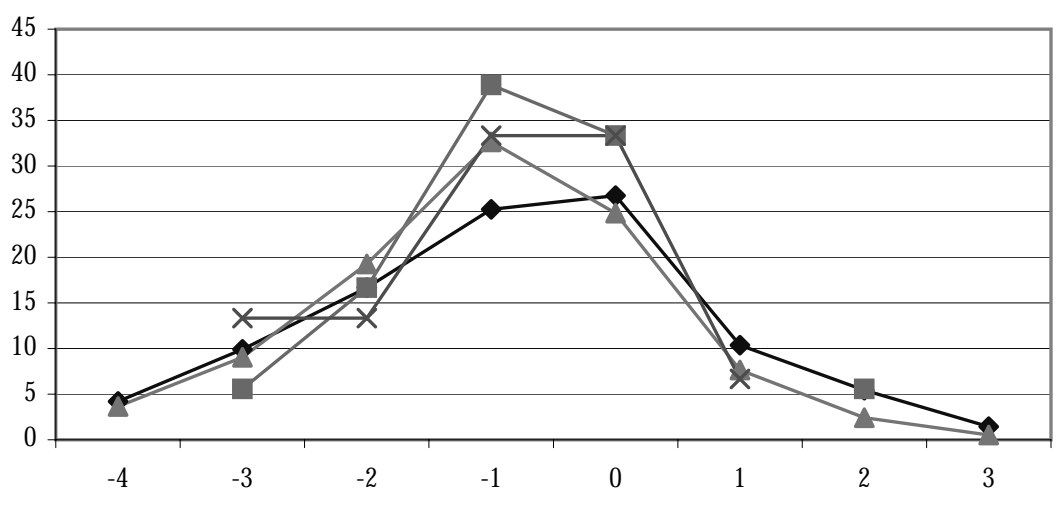

$\multimap$ Lo SES - Lo SES, SSE $\multimap$ African-American $\rightarrow$ Afr-Am SSE
Males
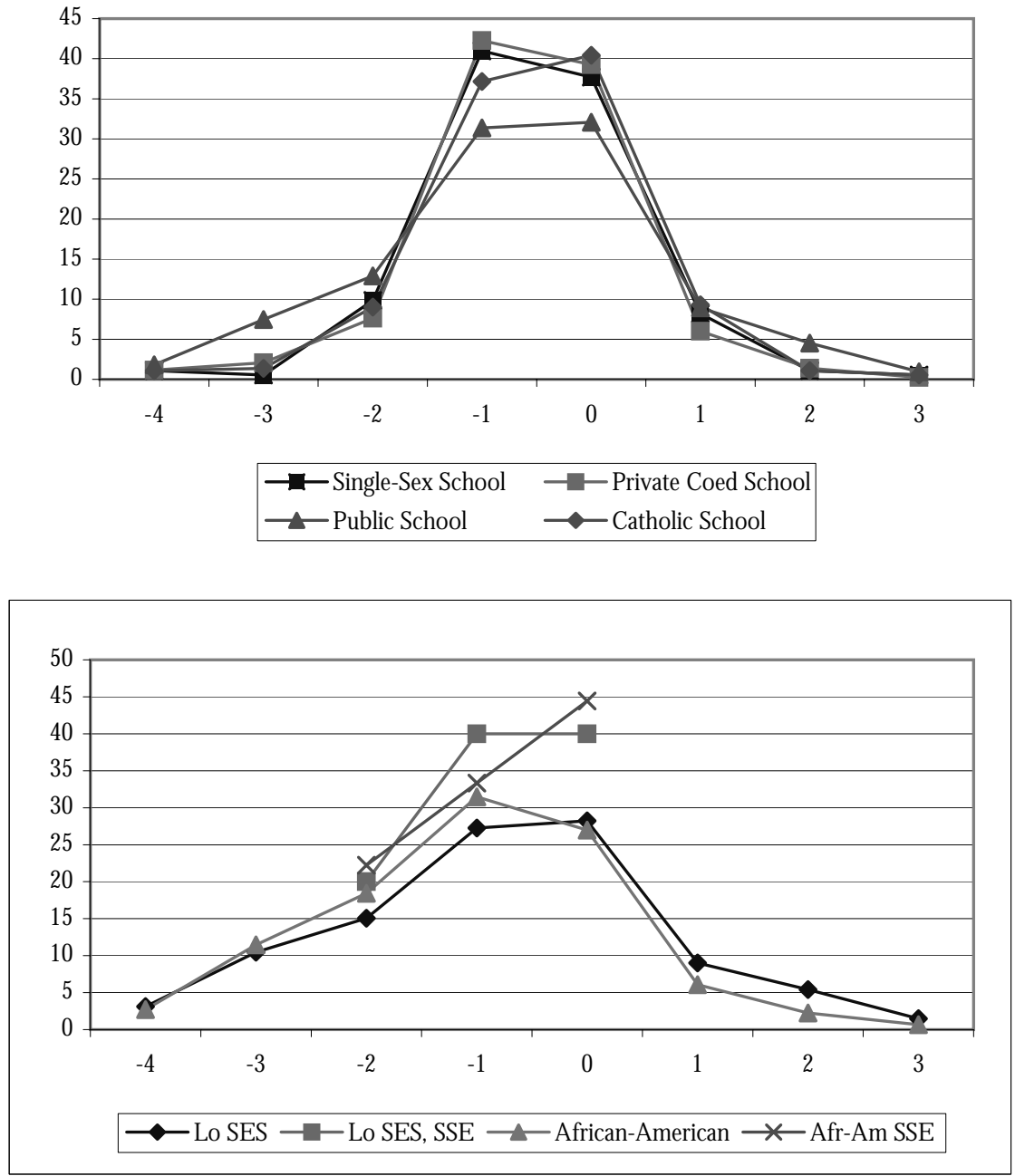
Figure 2. The Effect of Private, Catholic, and Single-Sex Education on Starting Salaries Women
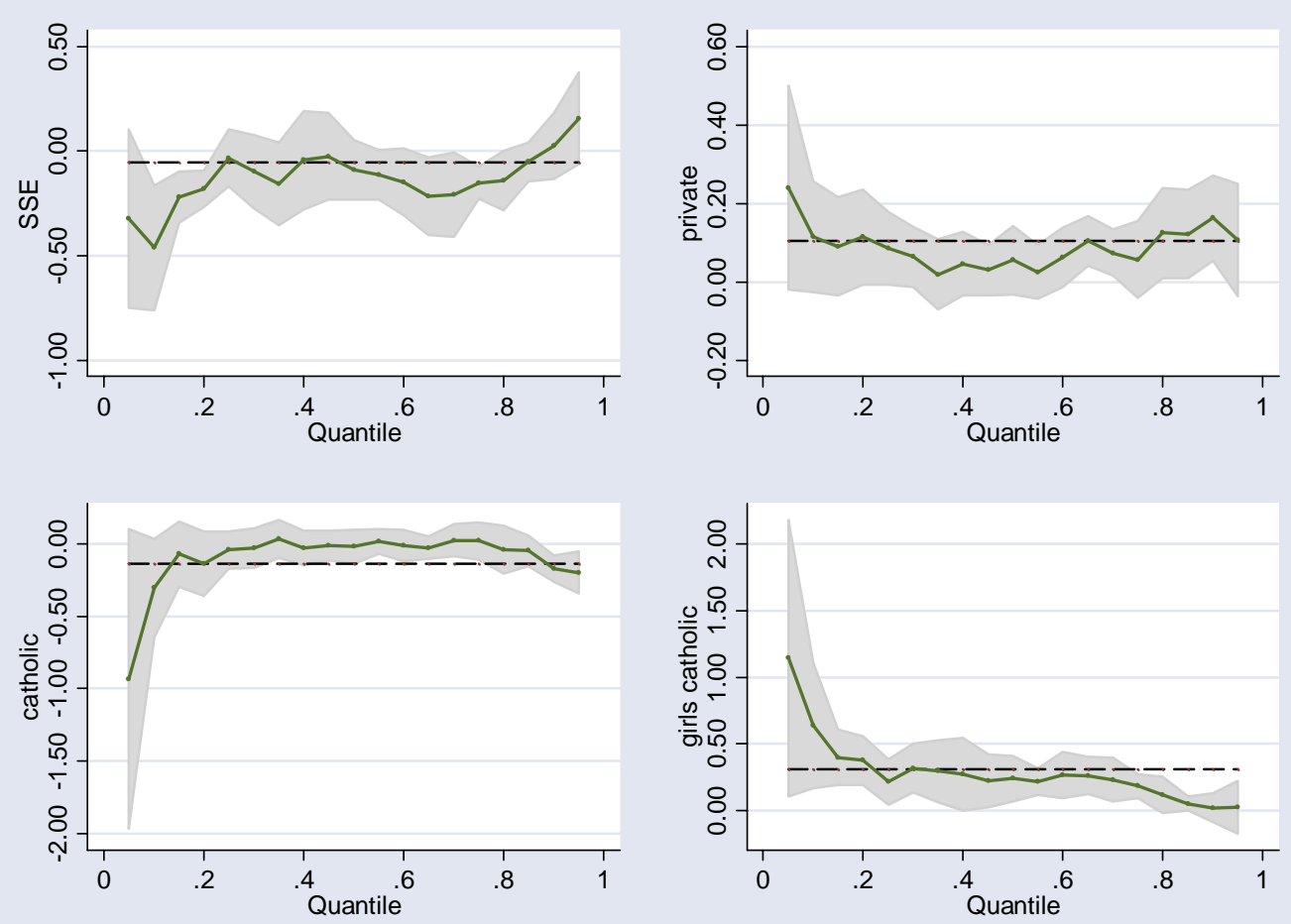

\section{Men}
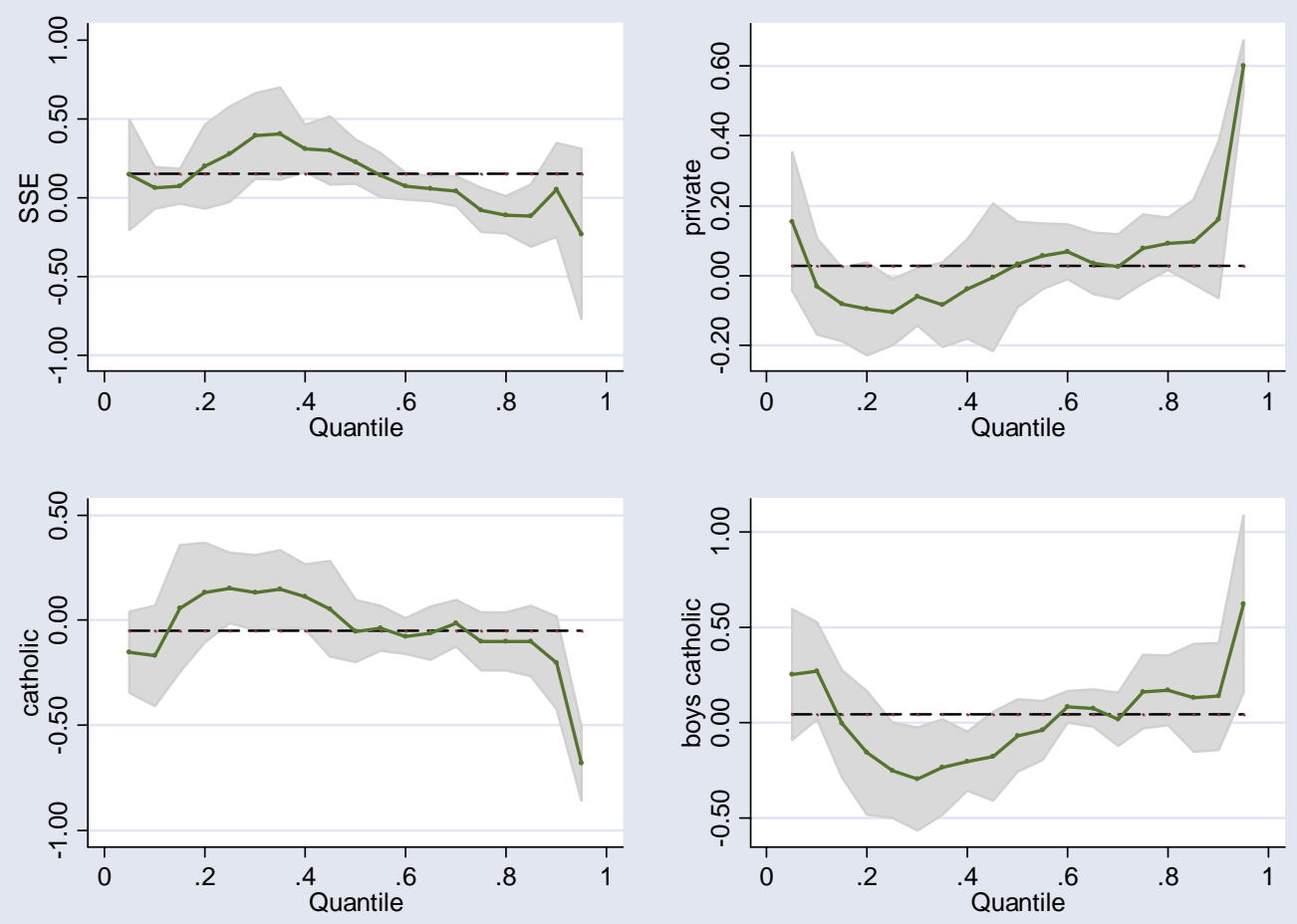
Table 1. Summary Statistics

$\begin{array}{lllrl} & \text { Females } & & \text { Males } \\ \text { Private } & \text { Private Public Private Private Public }\end{array}$ Single-Sex Coeducation Coeducation Single-Sex Coeducation Coeducation

\begin{tabular}{lrrrrrr} 
Reading Score & 56.66 & 55.47 & 51.43 & 56.73 & 54.36 & 49.67 \\
& $(8.74)$ & $(9.59)$ & $(10.05)$ & $(9.14)$ & $(9.97)$ & $(9.84)$ \\
Math Score & 54.43 & 54.66 & 50.25 & 57.32 & 55.10 & 50.91 \\
& $(9.75)$ & $(8.89)$ & $(9.92)$ & $(8.80)$ & $(9.69)$ & $(10.17)$ \\
Science Score & 53.12 & 51.63 & 49.64 & 55.84 & 55.21 & 51.71 \\
& $(9.37)$ & $(9.13)$ & $(9.41)$ & $(9.30)$ & $(10.63)$ & $(10.58)$ \\
Percent & 9.47 & 2.99 & 26.95 & 2.65 & 2.89 & 24.39 \\
in Lowest SES & $(29.36)$ & $(17.05)$ & $(44.38)$ & $(16.13)$ & $(16.78)$ & $(42.94)$ \\
Percent & 63.68 & 60.47 & 19.25 & 61.17 & 63.91 & 20.58 \\
in Highest SES & $(48.21)$ & $(48.94)$ & $(17.05)$ & $(48.86)$ & $(48.07)$ & $(40.43)$ \\
Single-Sex School & 0.223 & 0.085 & 0.038 & 0.187 & 0.038 & 0.029 \\
in Zip Code & $(0.418)$ & $(0.278)$ & $(0.190)$ & $(0.391)$ & $(0.191)$ & $(0.169)$ \\
Expect to go to & 0.920 & 0.940 & 0.790 & 0.977 & 0.870 & 0.752 \\
College & $(0.27)$ & $(0.24)$ & $(0.41)$ & $(0.15)$ & $(0.34)$ & $(0.43)$ \\
Attended & 0.000 & 0.015 & 0.006 & 0.001 & 0.004 & 0.003 \\
Single-Sex College & $(0.00)$ & $(0.12)$ & $(0.08)$ & $(0.03)$ & $(0.06)$ & $(0.06)$ \\
Received College & 0.381 & 0.370 & 0.334 & 0.293 & 0.292 & 0.256 \\
Scholarship & $(0.49)$ & $(0.48)$ & $(0.47)$ & $(0.46)$ & $(0.46)$ & $(0.44)$ \\
Eamed BA/ BS & 0.641 & 0.589 & 0.309 & 0.610 & 0.520 & 0.247 \\
& $(0.48)$ & $(0.49)$ & $(0.46)$ & $(0.49)$ & $(0.50)$ & $(0.43)$ \\
Eamed Post-G rad & 0.087 & 0.096 & 0.037 & 0.073 & 0.058 & 0.022 \\
Degree & $(0.28)$ & $(0.29)$ & $(0.19)$ & $(0.26)$ & $(0.23)$ & $(0.15)$ \\
Income in 1999 & $28,158.06$ & $25,546.00$ & $21,639.32$ & $43,298.36$ & $33,523.68$ & $29,553.41$ \\
& $(13310.33)$ & $(13404.76)$ & $(14291.06)$ & $(22129.10)$ & $(29443.12)$ & $(20211.01)$ \\
Median Income, & $31,016.63$ & $32,663.38$ & $29,889.76$ & $35,916.01$ & $36,310.43$ & $32,924.80$ \\
Chosen Occupation & $(11602.47)$ & $(10485.60)$ & $(12379.25)$ & $(17557.84)$ & $(16665.22)$ & $(14798.27)$ \\
& & & & & & \\
Observations & 186 & 468 & 4875 & 188 & 449 & 4183 \\
\hline Dat N & 186 & & & &
\end{tabular}

D ata: National Educational Longitudinal Study, Private School Survey, O ccupational Employment Statistics.

Standard deviations in parentheses. 
Table 2. Probability of Attending a Single-Sex School

\begin{tabular}{|c|c|c|c|c|}
\hline & \multicolumn{2}{|c|}{ Females } & \multicolumn{2}{|c|}{ Males } \\
\hline & All Students & Private Schools & All Students & Private Schools \\
\hline \multirow[t]{2}{*}{ African-American } & -0.007 & $0.259^{* *}$ & -0.002 & 0.227 \\
\hline & {$[0.005]$} & [0.118] & {$[0.005]$} & [0.173] \\
\hline Lowest Socioeconomic & 0.003 & $0.427 * * *$ & $-0.011 * * *$ & -0.138 \\
\hline Quartile & {$[0.007]$} & [0.122] & {$[0.004]$} & [0.157] \\
\hline Second Socioeconomic & 0.004 & 0.08 & $-0.009 * * *$ & $-0.229 * * *$ \\
\hline Quartile & {$[0.007]$} & {$[0.104]$} & {$[0.003]$} & {$[0.084]$} \\
\hline Highest Socioeconomic & 0.019 ** & 0.072 & -0.00005 & $-0.202^{* * *}$ \\
\hline Quartile & {$[0.009]$} & {$[0.077]$} & {$[0.003]$} & {$[0.074]$} \\
\hline \multirow[t]{2}{*}{ Reading Score } & $0.0005^{*}$ & 0.006 & $0.0003 * *$ & 0.002 \\
\hline & {$[0.0002]$} & {$[0.005]$} & [0.0002] & {$[0.005]$} \\
\hline \multirow[t]{2}{*}{ Math Score } & -0.0002 & -0.005 & 0.0002 & $0.010^{* *}$ \\
\hline & {$[0.0003]$} & {$[0.005]$} & [0.0002] & {$[0.005]$} \\
\hline \multirow[t]{2}{*}{ Science Score } & 0.00001 & 0.007 & -0.0003 & -0.001 \\
\hline & {$[0.0003]$} & {$[0.005]$} & {$[0.0002]$} & {$[0.004]$} \\
\hline \multirow[t]{2}{*}{ Expect to go to College } & 0.003 & -0.114 & $0.010^{* * *}$ & $0.392^{* * *}$ \\
\hline & {$[0.006]$} & [0.121] & {$[0.003]$} & {$[0.060]$} \\
\hline \multirow[t]{2}{*}{ Religious Participation } & $-0.009 * *$ & $-0.197 * * *$ & 0.001 & $-0.195^{* *}$ \\
\hline & {$[0.004]$} & {$[0.064]$} & [0.003] & {$[0.076]$} \\
\hline \multirow[t]{2}{*}{ Urban Residence } & $0.072^{* * *}$ & 0.072 & $0.088 * * *$ & $0.424^{* * *}$ \\
\hline & {$[0.012]$} & {$[0.064]$} & {$[0.016]$} & {$[0.053]$} \\
\hline Girls' School in & $0.075^{* * *}$ & $0.303 * * *$ & & \\
\hline Zip Code & {$[0.024]$} & {$[0.087]$} & & \\
\hline Boys' School in & & & $0.038 * *$ & $0.387 * * *$ \\
\hline Zip Code & & & {$[0.017]$} & {$[0.079]$} \\
\hline Pseudo R-squared & 0.209 & & 0.353 & \\
\hline Observations & 4503 & 629 & 3957 & 598 \\
\hline
\end{tabular}


Table 3. Bachelor's Degree Attainment and Scholarship Receipt

Females

Males

Probit Prob(BA) Prob(BA) Probit Probit Prob(BA) Prob(BA) Probit

Marg. Effects Single-Sex Coeducation Rec. Scholarship Marg. Effects Single-Sex Coeducation Rec. Scholarship (1)

(2) (3) (4) (5)

(6) (7) (8)

\begin{tabular}{|c|c|c|c|c|c|c|c|c|}
\hline Private School & $\begin{array}{l}0.167 \text { akek } \\
{[0.053]}\end{array}$ & 0.645 & 0.591 & $\begin{array}{l}-0.005 \\
{[0.044]}\end{array}$ & $\begin{array}{l}0.548^{\text {*ak }} \\
{[0.169]}\end{array}$ & 0.692 & 0.548 & $\begin{array}{l}0.0401 \\
{[0.046]}\end{array}$ \\
\hline $\begin{array}{l}\text { Lowest Socioeconomic } \\
\text { Quartile }\end{array}$ & $\begin{array}{l}-0.275^{* k *} \\
{[0.026]}\end{array}$ & 0.413 & 0.138 & $\begin{array}{l}0.023 \\
{[0.032]}\end{array}$ & $\begin{array}{l}-0.514^{* k} \\
{[0.099]}\end{array}$ & 0.614 & 0.105 & $\begin{array}{l}0.0088 \\
{[0.035]}\end{array}$ \\
\hline $\begin{array}{l}\text { Highest Socioeconomic } \\
\text { Quartile }\end{array}$ & $\begin{array}{l}0.109^{\text {ratek }} \\
{[0.031]}\end{array}$ & 0.780 & 0.689 & $\begin{array}{l}-0.184^{* 1 *} \\
{[0.027]}\end{array}$ & $\begin{array}{l}0.648^{* * *} \\
{[0.082]}\end{array}$ & 0.769 & 0.627 & $\begin{array}{l}-0.0193 \\
{[0.029]}\end{array}$ \\
\hline African-American & $\begin{array}{l}0.071 \\
{[0.046]}\end{array}$ & 0.932 & 0.304 & $\begin{array}{l}0.320^{1+1 k} \\
{[0.036]}\end{array}$ & $\begin{array}{l}-0.235 \\
{[0.175]}\end{array}$ & 0.561 & 0.150 & $\begin{array}{l}0.0397 \\
{[0.060]}\end{array}$ \\
\hline White & & 0.623 & 0.415 & & & 0.698 & 0.341 & \\
\hline Observations & 3307 & 101 & 3206 & 3307 & 2989 & 126 & 2852 & 2989 \\
\hline
\end{tabular}

Robust standard emors in brackets. * significant at 10\%; ** significant at 5\%; *** significant at 1\%

Additional regressors include additional race/ ethnicity, test soores, and a constant term.

Conditional estimated probabilities from models adjusting for sample selection into the treatment group of single-sex or coeducation. 
Table 4. College Major Choice

$\begin{array}{ccccc} & \text { Females } & & \text { Males } \\ \text { Private Private Public Private Private Public }\end{array}$ Single-Sex Coeducation Coeducation Single-Sex Coeducation Coeducation

College Major

\begin{tabular}{lcccccc} 
Philosophy \& Religion & 0.38 & 2.43 & 0.38 & 5.39 & 0.58 & 0.66 \\
Language & 0.70 & 0.31 & 0.54 & 0.11 & 0.66 & 0.23 \\
Culture Studies & 1.06 & 1.37 & 0.64 & 0.80 & 1.24 & 0.61 \\
Doctors/ D entists & 0.18 & 0.32 & 0.72 & 0.37 & 0.08 & 0.67 \\
Mathematics & 2.11 & 3.45 & 0.72 & 0.23 & 0.57 & 0.62 \\
Agriculture \& Forestry & 0.00 & 0.00 & 0.76 & 1.72 & 1.20 & 2.05 \\
Home \& Leisure & 0.00 & 0.72 & 0.95 & 0.00 & 0.00 & 1.11 \\
Mechanical & 0.00 & 0.21 & 1.05 & 0.90 & 1.63 & 8.60 \\
Literature & 5.51 & 1.42 & 1.38 & 2.71 & 4.34 & 0.94 \\
Performing Arts & 1.13 & 1.40 & 1.59 & 2.49 & 1.21 & 2.10 \\
Cosmetology & 0.23 & 0.00 & 1.84 & 0.00 & 0.00 & 0.20 \\
Law & 0.23 & 1.51 & 1.84 & 0.50 & 0.64 & 0.86 \\
Engineering & 0.30 & 2.68 & 1.94 & 9.33 & 5.89 & 9.92 \\
Computer & 0.62 & 1.82 & 2.11 & 1.73 & 3.81 & 3.83 \\
Art \& Architecture & 3.40 & 3.67 & 2.46 & 2.56 & 1.53 & 3.33 \\
Communications & 5.46 & 2.30 & 3.14 & 6.02 & 4.43 & 3.19 \\
Administrative Assistant & 4.82 & 0.28 & 3.17 & 3.93 & 1.53 & 0.75 \\
Science & 11.61 & 3.88 & 4.63 & 4.75 & 6.22 & 5.52 \\
Social Sciences & 12.96 & 11.77 & 9.37 & 8.52 & 7.71 & 7.04 \\
Business \& Economics & 7.59 & 12.03 & 13.46 & 19.69 & 16.14 & 15.09 \\
Miscellaneous & 19.25 & 6.89 & 14.08 & 20.18 & 26.74 & 20.45 \\
Education & 6.86 & 19.79 & 15.49 & 4.60 & 3.83 & 5.67 \\
Health & 15.60 & 21.74 & 17.23 & 3.49 & 9.91 & 6.55 \\
& & & & & & \\
Duncan Index & 33.17 & 40.82 & 29.05 & & & \\
\hline Dat N & &
\end{tabular}

D ata: National Educational Longitudinal Study, Private School Survey, Integrated Postsecondary Education D ata System.

D uncan Index reflects gender segregation within school type. 
Table 5. Effect of Single-Sex Schooling on Starting Salaries

\begin{tabular}{lllll} 
& \multicolumn{2}{c}{ Females } & Males \\
& All Schools & Private Schools & All Schools & Private Schools \\
\hline \multirow{2}{*}{ OLS estimate } & $0.211^{* * *}$ & $0.161^{*}$ & $0.161^{* * *}$ & $0.166^{*}$ \\
& {$[0.072]$} & {$[0.083]$} & {$[0.062]$} & {$[0.097]$} \\
$\mathrm{Q}=0.10$ & -0.020 & -0.216 & $0.148^{*}$ & 0.113 \\
& {$[0.183]$} & {$[0.108]$} & {$[0.085]$} & {$[0.121]$} \\
$\mathrm{Q}=0.25$ & -0.013 & 0.046 & 0.037 & 0.165 \\
& {$[0.076]$} & {$[0.094]$} & {$[0.108]$} & {$[0.110]$} \\
$\mathrm{Q}=0.50$ & $0.107^{* *}$ & 0.090 & $0.184^{* * *}$ & $0.175^{* * *}$ \\
& {$[0.022]$} & {$[0.060]$} & {$[0.039]$} & {$[0.057]$} \\
$\mathrm{Q}=0.75$ & 0.082 & $0.146^{* *}$ & $0.096^{*}$ & 0.0636 \\
& {$[0.066]$} & {$[0.065]$} & {$[0.054]$} & {$[0.060]$} \\
$\mathrm{Q}=0.90$ & 0.128 & 0.155 & $0.198^{*}$ & 0.130 \\
& {$[0.103]$} & {$[0.097]$} & {$[0.109]$} & {$[0.105]$} \\
& & & & \\
Observations & 2869 & 505 & 2939 & 516 \\
$\mathrm{R}$-squared & 0.31 & 0.29 & 0.16 & 0.35 \\
\hline Robust standard & & &
\end{tabular}

Robust standard errors in brackets

* significant at $10 \%$; ** significant at $5 \%$; *** significant at $1 \%$

Additional Regressors include race/ethinicity, degree attainment, marital status, hours worked, urban/rural, children, and a constant term.

Quantile regression estimates result from 500 bootstrapping repetitions. 
Table 6. Effect of Single-Sex Schooling on Median Salaries by Occupation

Females Males

All Schools Private Schools All Schools Private Schools

\begin{tabular}{lllll} 
OLS estimate & -0.06 & -0.069 & 0.019 & 0.012 \\
& {$[0.052]$} & {$[0.049]$} & {$[0.066]$} & {$[0.065]$} \\
$\mathrm{Q}=0.10$ & -0.017 & -0.031 & 0.066 & 0.052 \\
& {$[0.026]$} & {$[0.039]$} & {$[0.043]$} & {$[0.052]$} \\
$\mathrm{Q}=0.25$ & -0.046 & $-0.072^{* *}$ & $0.108^{*}$ & -0.027 \\
& {$[0.029]$} & {$[0.033]$} & {$[0.055]$} & {$[0.055]$} \\
$\mathrm{Q}=0.50$ & -0.008 & 0.000 & 0.038 & 0.034 \\
& {$[0.024]$} & {$[0.032]$} & {$[0.041]$} & {$[0.046]$} \\
$\mathrm{Q}=0.75$ & 0.030 & 0.009 & -0.012 & -0.072 \\
& {$[0.053]$} & {$[0.053]$} & {$[0.031]$} & {$[0.052]$} \\
$\mathrm{Q}=0.90$ & -0.021 & 0.020 & -0.035 & -0.029 \\
& {$[0.046]$} & {$[0.051]$} & {$[0.029]$} & {$[0.045]$} \\
& & & & \\
Observations & 3041 & 523 & 3044 & 531 \\
$\mathrm{R}-$-squared & 0.17 & 0.14 & 0.08 & 0.13 \\
\hline
\end{tabular}

Robust standard errors in brackets

* significant at $10 \%$; ** significant at $5 \%$; *** significant at $1 \%$

Additional Regressors include race/ethinicity, degree attainment, marital status, hours worked, urban/rural, children, and a constant term.

Quantile regression estimates result from 500 bootstrapping repetitions. 
Table 7. Predicted Wages Resulting from Selection-Corrected Regressions on Salary

\begin{tabular}{|c|c|c|c|c|c|c|c|c|}
\hline & \multicolumn{4}{|c|}{ Females } & \multicolumn{4}{|c|}{ Males } \\
\hline & \multirow{2}{*}{\multicolumn{2}{|c|}{$\begin{array}{c}\text { Starting Salaries } \\
\text { Single-Sex Coeducation }\end{array}$}} & \multicolumn{2}{|c|}{ Occupational Salaries } & \multicolumn{2}{|c|}{ Starting Salaries } & \multicolumn{2}{|c|}{ Occupational Salaries } \\
\hline & & & Single-Sex & Coeducation & Single-Sex & Coeducation & Single-Sex & Coeducation \\
\hline African-American & $30,424.67$ & $19,700.72$ & $36,089.46$ & $28,938.67$ & $37,958.08$ & $26,929.58$ & $26,349.12$ & $32,386.87$ \\
\hline Single & $31,865.45$ & $26,746.47$ & $32,119.79$ & $31,403.30$ & $31,644.26$ & $30,959.60$ & $37,243.44$ & $34,390.24$ \\
\hline Married & $25,241.34$ & $25,270.60$ & $33,146.15$ & $30,845.68$ & $34,853.80$ & $36,736.82$ & $31,724.31$ & $34,535.98$ \\
\hline H.S. Diploma & $25,509.95$ & $21,795.10$ & $28,323.60$ & $27,574.74$ & $32,807.72$ & $31,712.73$ & $31,121.69$ & $32,374.94$ \\
\hline BA/BS Degree & $30,673.94$ & $32,458.12$ & $33,788.17$ & $35,150.56$ & $38,589.97$ & $37,857.33$ & $43,434.79$ & $38,753.70$ \\
\hline Grad. Degree & $36,842.26$ & $30,200.12$ & $34,103.28$ & $42,781.50$ & $23,920.30$ & $31,516.97$ & $35,866.24$ & $46,126.55$ \\
\hline
\end{tabular}

